\title{
RANKING WOJEWÓDZTW ZE WZGLĘDU NA POTENCJAŁ ROLNICTWA
}

\author{
Joanna Kisielińska \\ Katedra Ekonomiki Rolnictwa i Międzynarodowych Stosunków Gospodarczych \\ Szkoły Głównej Gospodarstwa Wiejskiego w Warszawie \\ Kierownik katedry: dr hab. Joanna Kisielińska, prof. SGGW
}

\begin{abstract}
Słowa kluczowe: potencjał rolnictwa, metody porządkowania liniowego
Key words: agricultural potential, methods of linear ordering

S y n o p s i s. Celem badań było porównanie potencjału rolnictwa w województwach oraz ocena jego zmian w latach 2006 i 2014. Podstawą oceny były rankingi opracowane z wykorzystaniem wybranych metod porządkowania liniowego sporządzone ze względu na skuteczność i możliwości prowadzenia produkcji rolniczej, a nie na jej wielkość. Wykorzystując miarę podobieństwa rankingów wybrano dla obydwu lat najlepsze rankingi. Zmienne syntetyczne, na podstawie których je utworzono, wykorzystano następnie do wyodrębnienia klas typologicznych. Zaproponowano podział na pięć grup bazujący na średniej i odchyleniu standardowym.
\end{abstract}

\section{WSTĘP}

Wstąpienie Polski do Unii Europejskiej (UE) w 2004 roku znacznie zmieniło sytuację polskiego rolnictwa. Jest to związane z dostępem do rynków oraz funduszy UE. Wystarczy wspomnieć, że w latach 2004-2015 kwota płatności zrealizowanych w ramach płatności bezpośrednich wyniosła ponad $129 \mathrm{mld}$ zł [ARiMR 2016]. Miało to wpływ nie tylko na poziom życia rolników, ale również na warunki produkcji, które mogą być określane poprzez ocenę potencjału produkcyjnego rolnictwa. Ocena ta powinna uwzględniać nie tylko trzy podstawowe czynniki produkcji, czyli ziemię, pracę i kapitał, ale również czynnik intelektualny - przedsiębiorczość, stosowane technologie, organizację i zarządzanie (na co zwracali uwagę Augustyn Woś i Franciszek Tomczak [Woś, Tomczak 1983] za: Marią Orłowską [Orłowska 2014]). Czynnik intelektualny wpływa z pewnością na poziom produkcji, dochodów oraz efektywność gospodarowania.

Potencjał rolnictwa jest zjawiskiem złożonym, który nie może być określony za pomocą jednej zmiennej, lecz wielu. Analiza jego poziomu może być prowadzona jednowymiarowo (dla każdej cechy oddzielnie), jednak bardziej odpowiednie wydaje się podejście wielowymiarowe. Jedną z metod analizy wielowymiarowej jest porządkowanie liniowe obiektów, bazujące na zmiennych syntetycznych (ZS) wyznaczanych na podstawie wielu cech charakteryzujących badane zjawisko. Porządkowanie obiektów może być realizowane na wiele różnych sposobów.

Przykłady zastosowania metod porządkowania liniowego w ekonomice rolnictwa przedstawili Joanna Kisielińska i Stanisław Stańko [Kisielińska, Stańko 2009]. Z wymie- 
nionych tam autorów potencjałem rolnictwa zajmowali się Agata Binderman [Binderman 2005] oraz Anna Majchrzak i Feliks Wysocki [Majchrzak, Wysocki 2007]. Jako przykład nowszych prac wymienić można publikacje Feliksa Wysockiego i Agnieszki Kozery [Wysocki, Kozera 2012], Walentego Poczty i Natalii Bartkowiak [Poczta, Bartkowiak 2012], Luizy Osowskiej i Doroty Janiszewskiej [Osowska, Janiszewska 2013], Anny Nowak, Agnieszki Kamińskiej i Moniki Różańskiej-Baczuły [Nowak i in. 2014] i J. Kisielińskiej [Kisielińska 2016]. Poszczególni autorzy wykorzystywali różne zestawy cech charakteryzujących potencjał rolnictwa, których cechą wspólną było uniezależnianie ich wielkości od rozmiarów badanych obiektów. Wybrane charakterystyki przeliczano zwykle na hektary (bądź 100 ha) czy jednego zatrudnionego. W tabeli 1. przedstawiono obiekty, dla których tworzono rankingi oraz metody zastosowane w wymienionych badaniach.

Badania jednowymiarowe potencjału rolnictwa, prowadzone dla każdej zmiennej oddzielnie, zostały przedstawione m.in. w pracach: [Poczta, Kołodziejczak 2004, Poczta, Pawlak 2010, Nowak, Wójcik 2013, Orłowska 2014].

Tabela 1. Wybrane przykłady badań potencjału rolnictwa metodą porządkowania liniowego

\begin{tabular}{lll}
\hline \multicolumn{1}{c}{ Autor } & Obiekty & \multicolumn{1}{c}{ Metody } \\
\hline Binderman 2005 & województwa & $\begin{array}{l}\text { normalizacja zmiennych poprzez standaryzację, } \\
\text { przekształcenie ilorazowe i unitaryzację } \\
\text { zerowaną, ZS jest odległością Minkowskiego od } \\
\text { hipotetycznego wzorca }\end{array}$ \\
\hline $\begin{array}{l}\text { Majchrzak, } \\
\text { Wysocki 2007 }\end{array}$ & gminy z Wielkopolski & $\begin{array}{l}\text { normalizacja zmiennych metodą unitaryzacji } \\
\text { zerowanej, ZS jest odległością euklidesową od } \\
\text { najlepszego i najgorszego wzorca }\end{array}$ \\
\hline $\begin{array}{l}\text { Wysocki, } \\
\text { Kozera 2012 }\end{array}$ & województwa & $\begin{array}{l}\text { normalizacja zmiennych metodą unitaryzacji } \\
\text { zerowanej, ZS utworzono klasyczną metodą TOPSIS }\end{array}$ \\
\hline $\begin{array}{l}\text { Poczta, } \\
\text { Bartkowiak 2012 }\end{array}$ & województwa & $\begin{array}{l}\text { normalizacja zmiennych metodą unitaryzacji } \\
\text { zerowanej, ZS utworzono metodą bezwzorcową }\end{array}$ \\
\hline $\begin{array}{l}\text { Osowska, } \\
\text { Janiszewska 2013 }\end{array}$ & $\begin{array}{l}\text { gminy województwa } \\
\text { zachodniopomorskiego }\end{array}$ & $\begin{array}{l}\text { normalizacja zmiennych metodą unitaryzacji } \\
\text { zerowanej, ZS utworzono metodą bezwzorcową }\end{array}$ \\
\hline $\begin{array}{l}\text { Nowak, Kamińska, } \\
\text { Różańska-Baczuła }\end{array}$ & województwa & $\begin{array}{l}\text { normalizacja zmiennych metodą unitaryzacji } \\
\text { zerowanej, ZS utworzono metodą bezwzorcową }\end{array}$ \\
\hline Kisielińska 2016 & państwa & $\begin{array}{l}\text { zastosowano wiele metod i dokonano wyboru } \\
\text { ostatecznego rankingu wedle dwóch procedur }\end{array}$ \\
\hline
\end{tabular}

Źródło: opracowanie własne.

Przedmiotem badań było porównanie potencjału rolnictwa w województwach. Jako metodę badawczą wybrano porządkowanie liniowe, które pozwala na sporządzenie ich rankingu. Zastosowanie wielu metod wymagało zastosowania miary zaproponowanej przez Karola Kukułę [Kukuła 1986], pozwalającej wybrać spośród wielu rankingów najlepszy (najbardziej podobny do pozostałych). Na podstawie zmiennej syntetycznej, będącej podstawą ostatecznego rankingu, podzielono województwa na grupy typologiczne. Zaproponowano podział na pięć grup typologicznych wykorzystujących średnią arytmetyczną i odchylenie standardowe zmiennej syntetycznej. Analizy przeprowadzono dla lat 2006 i 2014, co pozwoliło ocenić relatywne zmiany potencjału rolnictwa w badanym okresie. Obliczenia wykonano z wykorzystaniem aplikacji Microsoft Excel. 


\section{METODYKA PRACY}

Metody porządkowania liniowego obiektów dobrano, opierając się na następujących pozycjach literatury: [Hellwig 1968, Bartosiewicz 1976, Nowak 1977, Strahl 1978, Borys 1978, Kukuła 1986, 2000, 2012, Grabiński 1992, Zeliaś 2002, Lira i in. 2002, Gatnar, Walesiak 2004, Pawełek 2008, Panek 2009, Walesiak 2011, 2014, 2016, Łuczak, Wysocki 2013, Kukuła, Luty 2015a, 2015b].

Sporządzanie rankingu obiektów prowadzono w następujących etapach:

1) dobór i selekcja zmiennych diagnostycznych,

2) normalizacja zmiennych,

3) wyznaczenie zmiennych syntetycznych stanowiących agregaty zmiennych diagnostycznych,

4) sporządzenie rankingu lub rankingów (jeśli stosowanych jest równocześnie wiele metod),

5) wybór rankingu ostatecznego.

Ad 1. Zestaw zmiennych diagnostycznych, stanowiący podstawę sporządzanych rankingów, decyduje o pozycji w nich zajmowanej przez poszczególne obiekty. Ich dobór powinien być podporządkowany celowi, w jakim ranking jest tworzony. Różne zestawy mogą skutkować odmienną oceną poziomu badanego zjawiska złożonego. W pierwszym etapie wyboru zmiennych brano pod uwagę kryteria merytoryczne (z uwzględnieniem dostępności danych). W etapie drugim prowadzono ich selekcję w oparciu o kryteria statystyczne. Najprostsza metoda wykorzystuje wartości współczynników korelacji Pearsona. Zbyt silna korelacja między zmiennymi powoduje, że zasoby informacji w nich zawarte są dublowane, wzmacniając ich wpływ na zmienną syntetyczną. Konieczne jest założenie granicznej wartości współczynnika korelacji ${ }^{1}$, powyżej którego wyeliminowana zostanie jedna ze zmiennych. Poziom tej wartości nie powinien być zbyt wysoki ze względu na dublowanie informacji, ale równocześnie nie może być zbyt niski, ponieważ może nastąpić znacząca jej utrata.

Ad 2. Normalizację zmiennych mającą na celu sprowadzenie ich do podobnego rzędu wielkości można przeprowadzić różnymi metodami, które porównał Marek Walesiak [Walesiak 2014]. W tabeli 2. przedstawiono formuły wykorzystywane w zastosowanych metodach w wariantach dla stymulant i destymulant ${ }^{2}$.

Ad 3. Unormowane zmienne pozwalają na wyznaczenie zmiennych syntetycznych, stanowiących podstawę tworzenia rankingów. Metody ich tworzenia podzielić można na dwie grupy: bezwzorcowe i wzorcowe. Najprostszą bezwzorcową metodą agregacji jest obliczenie średniej arytmetycznej z unormowanych zmiennych diagnostycznych lub średniej ważonej, jeżeli są przesłanki do uznania różnego ich wkładu na określenie badanego zjawiska złożonego. W metodach wzorcowych wykorzystuje się wartości zmiennych obiektów wybranych jako wzorcowe. Wzorcem może być tzw. dolny lub górny biegun rozwoju. Dolny biegun rozwoju (dla stymulant i destymulant przekształconych na stymulanty) tworzy fikcyjny obiekt o najmniejszych wartościach zmiennych, górny zaś o największych. W tabeli 3. przedstawiono metody wykorzystane w badaniach do tworzenia zmiennych syntetycznych.

$1 \quad$ Ponieważ badanie dotyczy całej populacji (wszystkich województw) nie można wykorzystywać testów statystycznych w celu określenia wartości krytycznej współczynnika korelacji.

2 Stymulantą (destymulantą) jest zmienna, której wysokie (niskie) wartości są pożądane z punktu widzenia badanego zjawiska złożonego. 
Tabela 2. Wybrane metody normalizacji

\begin{tabular}{|c|c|c|}
\hline Nazwa metody & Przekształcenie stymulant & Przekształcenie destymulant \\
\hline Standaryzacja & $z_{i j}=\frac{x_{i j}-\bar{x}_{j}}{s_{j}}$ & $z_{i j}=\frac{\bar{x}_{j}-x_{i j}}{s_{j}}$ \\
\hline $\begin{array}{l}\text { Unitaryzacja } \\
\text { zerowana }\end{array}$ & $z_{i j}=\frac{x_{i j}-\min _{i} x_{i j}}{\max _{i} x_{i j}-\min _{i} x_{i j}}$ & $z_{i j}=\frac{\max _{i} x_{i j}-x_{i j}}{\max _{i} x_{i j}-\min _{i} x_{i j}}$ \\
\hline $\begin{array}{l}\text { Metoda } \\
\text { Nowaka }\end{array}$ & $z_{i j}=\frac{x_{i j}}{\bar{x}_{j}}$ & $z_{i j}=\frac{\bar{x}_{j}}{x_{i j}}$ \\
\hline Metoda Strahl & $z_{i j}=\frac{x_{i j}}{\max _{i} x_{i j}}$ & $z_{i j}=\frac{\min _{i} x_{i j}}{x_{i j}}$ \\
\hline $\begin{array}{l}\text { Standaryzacja } \\
\text { pozycyjna }\end{array}$ & $z_{i j}=\frac{x_{j}-m \tilde{e} d_{j}}{1,4826 \cdot m \tilde{a} d_{j}}$ & $z_{i j}=\frac{\max _{i} x_{j}-x_{i j}-m \tilde{e} d_{j}}{1,4826 \cdot m \tilde{a} d_{j}}$ \\
\hline
\end{tabular}

Uwaga: w tabeli zastosowano następujące oznaczenia: $k$ - liczba zmiennych diagnostycznych, $n$ - liczba obiektów (województw), $x_{i j}-j$-ta zmienna diagnostyczna dla $i$-tego obiektu, $z_{i j}-$ unormowana obserwacja $x_{i j}, \bar{x}_{j}=\frac{1}{n} \sum_{i=1}^{n} x_{i j}, s_{j}=\sqrt{\frac{1}{n} \sum_{i=1}^{n}\left(x_{i j}-\bar{x}_{j}\right)^{2}}$, dla stymulant $m \tilde{a} d_{j}=m_{i} d\left|x_{i j}-m \tilde{e} d_{j}\right|$, a dla destymulant $m \tilde{a} d_{j}=\operatorname{med}_{i}\left|\max _{i} x_{i j}-x_{i j}-m \tilde{e} d_{j}\right|$, gdzie $\hat{\theta}=\left[m \tilde{e} d_{1}, m \tilde{e} d_{2}, \ldots, m \widetilde{e} d_{k}\right]^{T}$ jest medianą Webera stanowiącą rozwiązanie zadania optymalizacyjnego $\min _{\theta} \sum_{i=1}^{n} \sqrt{\sum_{j=1}^{n}\left(x_{i j}-\theta_{j}\right)^{2}}$

Źródło: opracowanie własne.

Ad 4. Wartości zmiennej syntetycznej określają pozycję obiektu w rankingu. Im wartość zmiennej jest większa (co wynika z zastosowanych metod normalizacji i wyznaczania zmiennych syntetycznych), tym pozycja obiektu jest wyższa.

Ad 5. Jeżeli do tworzenia rankingów wykorzystano wiele metod, pozycje poszczególnych obiektów mogą być w nich różne, na co zwracali uwagę K. Kukuła i Lidia Luty [Kukuła, Luty 2015a, 2015b]. Wybór ostatecznego rankingu umożliwia miara podobieństwa rankingów zaproponowana przez K. Kukułę [Kukuła 1986] o następującej postaci:

$$
\bar{u}_{p}=\frac{1}{v-1} \sum_{\substack{q=1 \\ q \neq p}}^{v}\left(1-\frac{2 \sum_{i=1}^{n}\left|c_{\substack{\dot{p} \\ i p}}-c_{\dot{\underline{i}}}\right|}{n^{2}-z}\right)
$$

gdzie: $v$ - liczba rankingów, $c_{i p}$ - pozycja $i$-tego obiektu w $p$-tym rankingu, zaś $z= \begin{cases}0, & n \bmod 2=0 \\ 1, & n \bmod 2=1\end{cases}$ 
Tabela 3. Wybrane metody tworzenia zmiennych syntetycznych

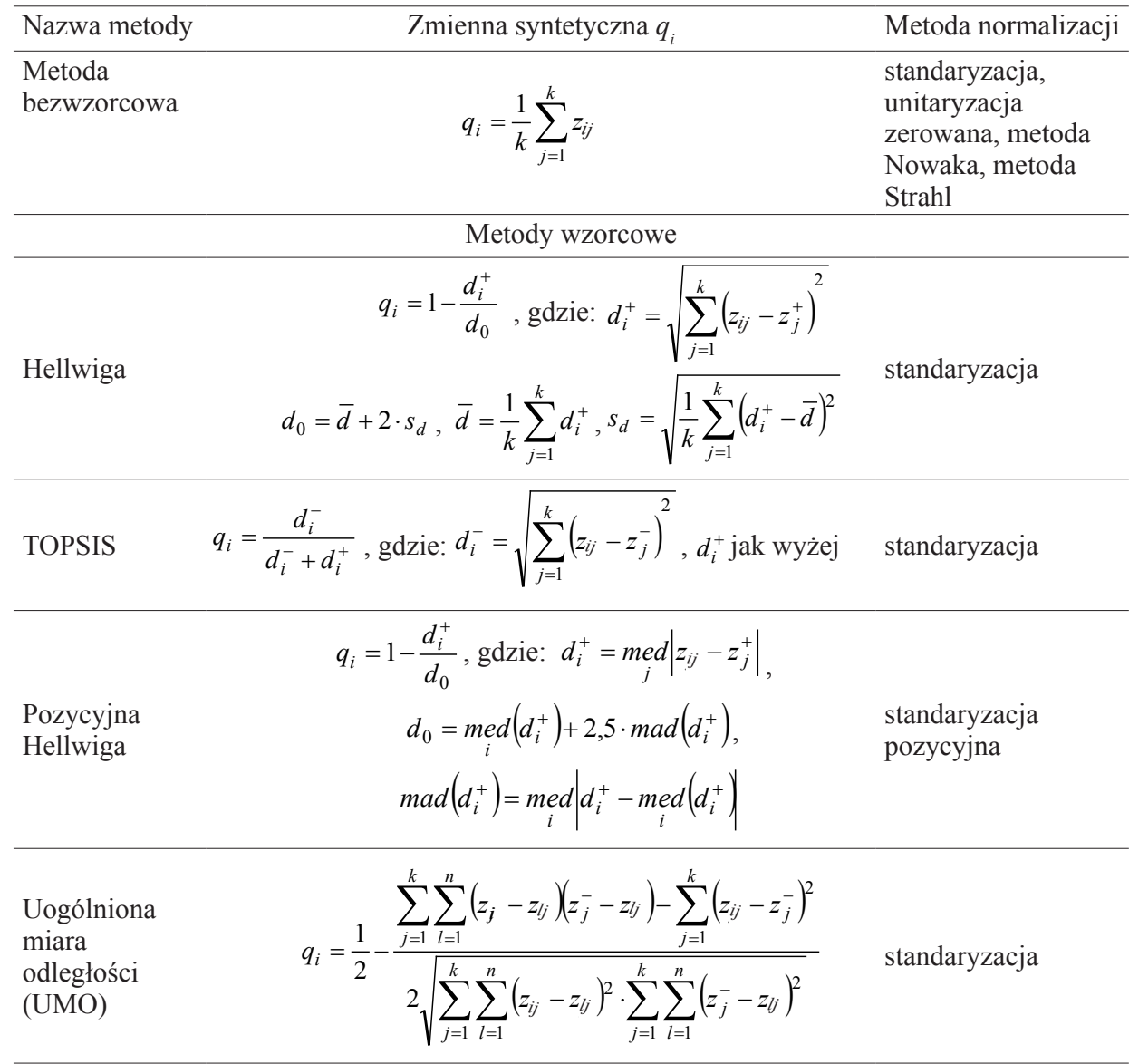
Ưwaga: w tabeli zastosowano następujące oznaczenia $z_{j}^{+}=\max _{i} z_{i j}$ i $z_{j}^{-}=\min _{i} z_{i j}$
Źródło: opracowanie własne.

Spośród rankingów wybierać należy ten, dla którego miara podobieństwa rankingów jest największa. Ranking ten jest bowiem najbardziej podobny do pozostałych.

Rankingi mogą być sporządzone dla jednego roku lub większej liczby lat. Ranking z jednego roku pozwala porównywać ze sobą różne obiekty ze względu na badane zjawisko złożone. Porównanie rankingów z różnych lat pozwala ocenić zmiany, które zachodzą dla obiektu w czasie. Obiekt, którego pozycja poprawia się wraz z upływem czasu, rozwija się szybciej w porównaniu do innych, lepiej wykorzystując środki, jakimi dysponuje, i odwrotnie. Obiekt, którego pozycja obniża się, nie rozwija się lub rozwija się słabiej niż inne, nie wykorzystując swojego potencjału.

Zmienna syntetyczna zastosowana do sporządzenia ostatecznego rankingu, może być następnie wykorzystana do wyodrębnienia w zbiorze obiektów klas typologicznych, które charakteryzuje podobny poziom badanego zjawiska złożonego. Jest to uzasadnione, ponieważ przy tworzeniu rankingu na podstawie zmiennej syntetycznej przekształca się ją na 
skalę porządkową, tracąc informację o różnicach pomiędzy poziomami badanego zjawiska złożonego, które mogą być między poszczególnymi obiektami małe, ale również i duże.

Klasy wyodrębnić można, wykorzystując średnią $(\bar{q})$ i odchylenie standardowe $\left(s_{q}\right)$ zmiennej syntetycznej. Najczęściej podziału na klasy dokonuje się (por. [Majchrzak, Wysocki 2007, Wysocki, Kozera 2012, Poczta, Bartkowiak 2012, Nowak i in. 2014]) w następujący sposób:

- $\quad$ klasa I (wysoki poziom badanego zjawiska): $q_{i} \geq \bar{q}+s_{q}$,

- $\quad$ klasa II (średni-wyższy poziom): $\bar{q}+s_{q}>q_{i} \geq \bar{q}$,

- $\quad$ klasa III (średni-niższy poziom): $\bar{q}>q_{i} \geq \bar{q}-s_{q}$,

- $\quad$ klasa IV (niski poziom): $\bar{q}-s_{q}>q_{i}$.

Gdyby zmienna syntetyczna miała rozkład normalny, przy takim podziale zbiorowości, klasa I objęłaby 15,9\% obiektów o jej najwyższych wartościach, klasa II - 34,1\% o wartości od średniej do średniej powiększonej o odchylenie standardowe, klasa III - 34,1\% o wartości od średniej zmniejszonej o odchylenie standardowe do średniej, a klasa IV $15,9 \%$ o najniższych wartościach. Można zaproponować bardziej równomierny podział zbiorowości np. wyróżniając 5 klas zawierających po 20\% obiektów. Dla zmiennej syntetycznej o rozkładzie normalnym taki podział byłby następujący:

- $\quad$ klasa I (bardzo wysoki poziom badanego zjawiska): $q_{i} \geq \bar{q}+0,8416 \cdot s_{q}$,

- $\quad$ klasa II (wysoki poziom): $\bar{q}+0,8416 \cdot s_{q}>q_{i} \geq \bar{q}+0,2533 \cdot s_{q}$,

- klasa III (średni poziom): $\bar{q}+0,2533 \cdot s_{q}>q_{i} \geq \bar{q}-0,2533 \cdot s_{q}$,

- $\quad$ klasa IV (niski poziom): $\bar{q}-0,2533 \cdot s_{q}>q_{i} \geq \bar{q}-0,8416 \cdot s_{q}$,

- $\quad$ klasa V (bardzo niski poziom): $\bar{q}-0,8416 \cdot s_{q}>q_{i}$.

Podział zbiorowości można także przeprowadzić ustalając inne proporcje. Należy jednak pamiętać, że jeśli zmienna syntetyczna ma rozkład odmienny od normalnego, udziały obiektów w poszczególnych klasach mogą być inne od przedstawionych. W pełni proporcjonalny podział można zapewnić, stosując miary pozycyjne (wybrane kwantyle). Ciekawe rozwiązanie oparte na rozstępie zmiennej syntetycznej zaproponował K. Kukuła [Kukuła 2014].

\section{BADANIA I WYNIKI}

W badaniach wykorzystano dane dotyczące rolnictwa dla 16 województw z lat 2006 i 2014 pochodzące z Rocznika statystycznego rolnictwa i obszarów wiejskich z 2007 r. [GUS 2007] oraz z Rocznika statystycznego rolnictwa z 2015 r. [GUS 2016]. Rankingi sporządzono w celu porównania potencjału rolnictwa w poszczególnych województwach, koncentrując się przede wszystkim nie na wielkości produkcji, lecz skuteczności i potencjalnych możliwościach jej prowadzenia. Po analizie merytorycznej wybrano następujące zmienne diagnostyczne:

$x_{1}$ - udział użytków rolnych (UR) w powierzchni województwa,

$x_{2}-$ udział gruntów ugorowanych,

$x_{3}$ - udział zmeliorowanych UR,

$x_{4}$ - pracujący w rolnictwie na 100 ha UR,

$x_{5}$ - nakłady inwestycyjne w rolnictwie i łowiectwie na 100 ha UR w tys. zł,

$x_{6}$-wartość brutto środków trwałych w rolnictwie i łowiectwie na 100 ha UR w tys. zł,

$x_{7}$ - zużycie nawozów mineralnych lub chemicznych na 1 ha UR w kg,

$x_{8}-$ globalna produkcja rolnicza na 1 ha UR w tys. zł. 
Wybrane zmienne charakteryzują podstawowe czynniki produkcji rolniczej oraz organizację tej produkcji. Wyznaczano je tak, aby wyeliminować wpływ na sporządzone rankingi wielkości poszczególnych województw. Ponieważ pozytywnie o potencjale rolnictwa świadczą wysokie wartości zmiennych $x_{1}, x_{3}, x_{5}, x_{6}, x_{7}$ oraz $x_{8}$, przyjęto, że są one stymulantami, destymulantami zaś zmienne $x_{2}$ i $x_{4}$. W badaniach przyjęto 0,8 jako wartość graniczną współczynnika korelacji Pearsona. Żadna para zmiennych diagnostycznych nie była skorelowana na poziomie wyższym od granicznej, dlatego wszystkie wykorzystano w dalszych analizach.

$\mathrm{W}$ tabeli 4. przedstawiono wybrane parametry rozkładów zmiennych diagnostycznych w latach 2006 i 2014. Wzrost średniej wartości zmiennych dla województw w badanym okresie nastąpił dla $x_{3}, x_{4}, x_{5}, x_{6}, x_{7}$ i $x_{8}$, spadek zaś dla $x_{1}$ i $x_{2}$. Obserwowane zmiany $\mathrm{z}$ punktu widzenia badanego zjawiska złożonego mogą być interpretowane jako niekorzystne jedynie w przypadku $x_{1}$ (udział UR w powierzchni województwa) i $x_{4}$ (pracujący $\mathrm{w}$ rolnictwie na 100 ha UR). Zmniejszenie udziału UR niekoniecznie musi oznaczać regres, ponieważ może być efektem eliminacji z użytkowania gruntów słabych czy przeznaczenie ich pod infrastrukturę (np. budownictwo). Niepokojące są zmiany średniej wartości $x_{4}$. Spadek zatrudnienia na 100 ha UR wystąpił jedynie dla dwóch województw (kujawsko-pomorskiego i podlaskiego), zatrudnienie nie zmieniło się w jednym (wielkopolskim), natomiast w pozostałych 13 województwach zwiększyło się. W przypadku pozostałych zmiennych zmiany są korzystne (wzrost średniej dla stymulant i spadek dla destymulant).

Znaki różnic między medianą i średnią pokazują kierunek asymetrii rozkładu. Znak dodatni (mediana większa od średniej) charakteryzuje asymetrię lewostronną oznaczającą przewagę w badanej zbiorowości jednostek o wysokich wartościach zmiennej. Znak ujemny wiąże się z asymetrią prawostronną, wskazującą na większy udział jednostek o niższych wartościach cechy. Lewostronnie asymetryczne rozkłady w 2006 roku miały jedynie zmienne $x_{1}$ i $x_{3}$, a w 2014 roku $-x_{3}, x_{7}$ i $x_{8}$. Uzasadnione jest przyjęcie, że dla stymulant korzystniejsza jest przewaga jednostek o wysokich wartościach cechy, a dla destymulant

Tabela 4. Wybrane parametry rozkładów zmiennych diagnostycznych dla 16 województw w latach 2006 i 2014

\begin{tabular}{|c|c|c|c|c|c|c|c|c|}
\hline \multirow[t]{2}{*}{ Parametr } & $x_{1}$ & $x_{2}$ & $x_{3}$ & $x_{4}$ & $x_{5}$ & $x_{6}$ & $x_{7}$ & $x_{8}$ \\
\hline & \multicolumn{8}{|c|}{2006} \\
\hline Średnia & 0,54 & 0,056 & 0,40 & 13 & 2,2 & 72 & 1210 & 3,9 \\
\hline Mediana & 0,55 & 0,055 & 0,42 & 12 & 1,8 & 70 & 1130 & 3,8 \\
\hline Współczynnik zmienności & 0,14 & 0,711 & 0,29 & 0,51 & 0,50 & 0,16 & 0,27 & 0,25 \\
\hline Wartość maksymalna & 0,65 & 0,173 & 0,62 & 26 & 4,6 & 101 & 1852 & 6,7 \\
\hline Wartość minimalna & 0,38 & 0,014 & 0,20 & 4 & 0,9 & 52 & 609 & 2,5 \\
\hline \multirow[t]{2}{*}{ Rozstęp } & 0,28 & 0,159 & 0,41 & 22 & 3,7 & 49 & 1242 & 4,1 \\
\hline & \multicolumn{8}{|c|}{$2014^{1}$} \\
\hline Średnia & 0,49 & 0,035 & 0,44 & 18 & 3,8 & 78 & 1291 & 5,8 \\
\hline Mediana & 0,48 & 0,031 & 0,45 & 12 & 3,3 & 75 & 1305 & 6,3 \\
\hline Współczynnik zmienności & 0,20 & 0,472 & 0,25 & 0,73 & 0,50 & 0,22 & 0,24 & 0,23 \\
\hline Wartość maksymalna & 0,63 & 0,073 & 0,62 & 50 & 8,9 & 119 & 1880 & 7,9 \\
\hline Wartość minimalna & 0,33 & 0,018 & 0,23 & 5 & 1,6 & 55 & 801 & 2,9 \\
\hline Rozstęp & 0,30 & 0,055 & 0,39 & 45 & 7,3 & 64 & 1078 & 5,0 \\
\hline
\end{tabular}

Uwaga: ${ }^{1}$ dla roku 2014 zmienne $x_{5}, x_{6}$ i $x_{8}$ przeliczono na ceny stałe z 2006 roku Źródło: opracowanie własne. 
przeciwnie. W takim przypadku można stwierdzić, że asymetria ma kierunek pożądany dla zmiennych $x_{1}, x_{2}, x_{3}$ i $x_{4}$ w 2006 roku i $x_{2}, x_{3}, x_{4}, x_{7}$ i $x_{8} \mathrm{~W} 2014$, niepożądany zaś dla $x_{5}$, $x_{6}, x_{7}$ i $x_{8} \mathrm{w} 2006$ roku i $x_{1}, x_{5}$ i $x_{6} \mathrm{w} 2014$. Korzystne zmiany asymetrii nastąpiły więc dla zmiennych $x_{7}$ (zużycie nawozów mineralnych lub chemicznych na 1 ha UR) i $x_{8}$ (globalna produkcja rolnicza na 1 ha UR), niekorzystne zaś dla $x_{1}$ (udział UR w powierzchni).

Analiza jednowymiarowa zmiennych diagnostycznych została przeprowadzona dla 2014 roku. Największy udział UR w powierzchni (zmienna $x_{1}$ ) miały województwa: wielkopolskie $(0,63)$, kujawsko-pomorskie $(0,62)$ oraz lubelskie $(0,57)$, najmniejszy zaś lubuskie $(0,33)$, podkarpackie $(0,35)$ i zachodniopomorskie $(0,35)$. Zróżnicowanie tej cechy oceniane współczynnikiem zmienności było słabe [Wasilewska 2009, s. 169], wartość maksymalna była niemal dwukrotnie większa od minimalnej.

Udział gruntów ugorowanych $\left(x_{2}\right)$ był najmniejszy w województwach: opolskim, lubelskim i wielkopolskim $(0,018)$, natomiast największy - lubuskim $(0,073)$, warmińsko-mazurskim $(0,061)$ oraz zachodniopomorskim $(0,060)$. Wartość maksymalna była czterokrotnie większa od najmniejszej, a zróżnicowanie cechy silne. Podkreślić należy, że zmienna ta miała bardzo małe wartości dla wszystkich województw.

Udział zmeliorowanych UR $\left(x_{3}\right)$ jest traktowany jako stymulanta ze względu na potencjał rolnictwa, z drugiej jednak strony, jeśli weźmie się pod uwagę małe zasoby wody w Polsce ocena cechy nie jest tak jednoznaczna. Melioracjom rzadko bowiem towarzyszyła budowa zbiorników wodnych, co skutkuje obniżaniem poziomu wód gruntowych. Największy udział zmeliorowanych UR miały województwa warmińsko-mazurskie $(0,62)$, pomorskie $(0,58)$ oraz śląskie $(0,55)$, najmniejszy zaś lubelskie $(0,23)$, świętokrzyskie $(0,24)$ i podlaskie $(0,33)$. Zróżnicowanie cechy było umiarkowane, a relacja wartości maksymalnej do minimalnej wyniosła prawie 3.

Liczba pracujących w rolnictwie na 100 ha UR $\left(x_{4}\right)$ była największa w województwach małopolskim (50), podkarpackim (45) i świętokrzyskim (31), natomiast najmniejsza w zachodniopomorskim (5), warmińsko-mazurskim (7) i lubuskim (8). Była to jedyna cecha, której zróżnicowanie było bardzo silne, wartość maksymalna była większa od minimalnej ponaddziewięciokrotnie.

Największe nakłady inwestycyjne w rolnictwie i łowiectwie na 100 ha UR $\left(x_{5}\right)$ ponoszono w województwach śląskim $(11,0$ tys. zł), lubuskim $(8,2)$ oraz opolskim $(7,0)$, najmniejsze w lubelskim $(2,0)$, mazowieckim $(2,3)$ i kujawsko-pomorskim $(2,4)$. Zróżnicowanie cechy było silne, a relacja wartości maksymalnej do minimalnej wyniosła ponad 5 .

Wartość brutto środków trwałych w rolnictwie i łowiectwie na 100 ha UR była największa $\left(x_{6}\right)$ w województwach śląskim (147 tys. zł), małopolskim (128) i wielkopolskim (110), natomiast najmniejsza w lubuskim (68), zachodniopomorskim (76) i warmińsko-mazurskim (77). Zróżnicowanie cechy było umiarkowane, wartość maksymalna była większa od minimalnej ponaddwukrotnie.

Największe zużycie nawozów mineralnych lub chemicznych na 1 ha UR $\left(x_{7}\right)$ występowało w województwach opolskim $(1880 \mathrm{~kg})$, dolnośląskim (1689) i kujawsko-pomorskim (1662), najmniejsze w podkarpackim (801), małopolskim (846) i lubuskim (980). Zróżnicowanie cechy było umiarkowane, a relacja wartości maksymalnej do minimalnej wyniosła ponad 2.

Największą wartość globalnej produkcji rolniczej na 1 ha UR $\left(x_{8}\right)$ osiągano w województwach opolskim $(9,7$ tys. zł), świętokrzyskim $(8,7)$ i lubelskim $(8,5)$, najmniejszą zaś w podlaskim $(3,6)$, warmińsko-mazurskim i podkarpackim $(4,8)$. Zróżnicowanie cechy było umiarkowane, wartość maksymalna była większa od minimalnej prawie trzykrotnie. 
Z przedstawionej analizy jednowymiarowej dla 2014 roku (dla roku 2006 było podobnie) wynika, że nie było województwa, w którym wszystkie cechy przyjęły wartości najbardziej bądź najmniej pożądane. Nie można więc na jej podstawie dokonać oceny badanego zjawiska złożonego - konieczna jest analiza wielowymiarowa.

Zróżnicowanie cech oceniane współczynnikiem zmienności było wprawdzie bardzo silne jedynie dla zmiennej $x_{2}$ w 2006 roku i $x_{4}$ w 2014, silne dla $x_{4}$ i $x_{5}$ w 2006 roku oraz $x_{2}$ i $x_{5} \mathrm{~W} 2014$, słabe dla $x_{1}$ i $x_{6} \mathrm{w} 2006$ roku, a w pozostałych przypadkach umiarkowane, to zmienność cech można uznać za wystarczającą, aby na jej podstawie tworzyć rankingi.

Rankingi województw ze względu na potencjał rolnictwa sporządzono różnymi metodami dla lat 2006 i 2014, oznaczając je następująco:

- metoda bezwzorcowa, normalizacja cech poprzez standaryzację (R1),

- metoda bezwzorcowa, normalizacja cech metodą unitaryzacji zerowanej (R2),

- metoda bezwzorcowa, normalizacja cech metodą Nowaka (R3),

- metoda bezwzorcowa, normalizacja cech metodą Strahl (R4),

- $\quad$ wskaźnik rozwoju Hellwiga, normalizacja cech poprzez standaryzację (R5)

- metoda TOPSIS, normalizacja cech poprzez standaryzację (R6),

- metoda pozycyjna, normalizacja cech poprzez standaryzację pozycyjną z medianą Webera (R7),

- uogólniona miara odległości (UMO), normalizacja cech poprzez standaryzację (R8).

W tabeli 5. przedstawiono pozycje poszczególnych województw w rankingach sporządzonych ze względu na potencjał rolnictwa dla lat 2006 i 2014. Różnice w pozycjach poszczególnych obiektów w rankingach sporządzonych różnymi metodami mogą być bardzo duże (dla województwa lubuskiego różnica wynosiła 10 w 2006 roku, a dla zachodniopomorskiego 9 w 2006 i 8 w 2014 roku). Różnice większe niż 4 w 2006 roku wystąpiły ponadto dla województw mazowieckiego i warmińsko-mazurskiego (7), małopolskiego (6) oraz świętokrzyskiego (5), a w 2014 roku dla lubuskiego (6), mazowieckiego i świętokrzyskiego (5). Jedynie dla dwóch województw w obydwu latach pozycja we wszystkich rankingach była taka sama. Wyniki te potwierdzają spostrzeżenie K. Kukuły i L. Luty [Kukuła, Luty 2015a, 2015b] o możliwości wystąpienia różnic w pozycjach w rankingach uzyskanych różnymi metodami oraz konieczności stosowania miary określonej formułą (1), pozwalającej wybrać ranking najlepszy, czyli najbardziej podobny do pozostałych.

W tabeli 6. przedstawiono miary podobieństwa dla 8 rankingów w latach 2006 i 2014. Rankingi posortowano w kolejności malejącej $\bar{u}_{p}$. W obydwu latach porządek jest niemal jednakowy z wyjątkiem pierwszej i drugiej pozycji. Najbardziej podobny do pozostałych w 2006 roku jest ranking R1 (agregacja bezwzorcowa, normalizacja metodą standaryzacji), a w 2014 roku R2 (agregacja bezwzorcowa, normalizacja cech metodą unitaryzacji zerowanej). Drugi w kolejności jest w 2006 roku ranking R2, a 2014 R1. Na pozycji trzeciej pod względem podobieństwa jest ranking R6 (metoda TOPSIS), a na czwartej R8 (UMO). Najmniej podobne do pozostałych były rankingi R3 (agregacja bezwzorcowa, normalizacja metodą Nowaka) oraz R7 (agregacja pozycyjna, normalizacja pozycyjna z medianą Webera). Podkreślić jednak należy, że wszystkie otrzymane rankingi należy uznać za podobne, o czym świadczą miary podobieństwa ${ }^{3}$ powyżej 0,9 oraz niemal 0,9 (R3 w 2014 roku).

Porównanie pozycji poszczególnych województw w latach 2006 i 2014 wymaga wyboru jednej metody sporządzania rankingów. Wybrano ranking $\mathrm{R} 1$, ponieważ miara podobieństwa w roku 2014 była wprawdzie mniejsza od rankingu R2, ale jedynie o 0,001, natomiast w 2006 roku większa o 0,003.

Miara podobieństwa rankingów mieści się w przedziale [0,1] [Kukuła, Luty 2015a, s. 223]. 
Tabela 5. Pozycje województw uzyskane wybranymi metodami porządkowania liniowego w 2006 roku

\begin{tabular}{|c|c|c|c|c|c|c|c|c|c|}
\hline Województwo & $\mathrm{R} 1$ & $\mathrm{R} 2$ & $\mathrm{R} 3$ & $\mathrm{R} 4$ & R5 & R6 & R7 & $\mathrm{R} 8$ & Rozstęp* \\
\hline \multicolumn{10}{|c|}{2006} \\
\hline wielkopolskie & 1 & 2 & 1 & 2 & 1 & 1 & 2 & 1 & 1 \\
\hline opolskie & 2 & 1 & 2 & 1 & 2 & 2 & 1 & 2 & 1 \\
\hline kujawsko-pomorskie & 3 & 3 & 3 & 3 & 3 & 3 & 3 & 3 & 0 \\
\hline lódzkie & 4 & 4 & 11 & 5 & 4 & 4 & 5 & 4 & 7 \\
\hline śląskie & 5 & 5 & 7 & 4 & 5 & 5 & 4 & 5 & 3 \\
\hline dolnośląskie & 6 & 6 & 8 & 10 & 7 & 7 & 8 & 7 & 4 \\
\hline warmińsko-mazurskie & 7 & 7 & 4 & 6 & 10 & 8 & 11 & 6 & 7 \\
\hline mazowieckie & 8 & 9 & 13 & 12 & 6 & 6 & 6 & 8 & 7 \\
\hline pomorskie & 9 & 8 & 9 & 8 & 8 & 9 & 7 & 9 & 2 \\
\hline podlaskie & 10 & 10 & 10 & 11 & 9 & 10 & 13 & 12 & 4 \\
\hline lubelskie & 11 & 13 & 12 & 13 & 13 & 11 & 14 & 10 & 4 \\
\hline lubuskie & 12 & 11 & 5 & 7 & 15 & 12 & 12 & 11 & 10 \\
\hline zachodniopomorskie & 13 & 12 & 6 & 9 & 14 & 15 & 15 & 13 & 9 \\
\hline małopolskie & 14 & 15 & 15 & 14 & 11 & 13 & 9 & 14 & 6 \\
\hline świętokrzyskie & 15 & 14 & 14 & 15 & 12 & 14 & 10 & 15 & 5 \\
\hline podkarpackie & 16 & 16 & 16 & 16 & 16 & 16 & 16 & 16 & 0 \\
\hline \multicolumn{10}{|c|}{2014} \\
\hline opolskie & 1 & 1 & 1 & 1 & 1 & 1 & 1 & 1 & 0 \\
\hline śląskie & 2 & 3 & 3 & 3 & 2 & 2 & 4 & 4 & 2 \\
\hline wielkopolskie & 3 & 2 & 2 & 2 & 3 & 3 & 3 & 2 & 1 \\
\hline kujawsko-pomorskie & 4 & 4 & 4 & 4 & 5 & 5 & 2 & 3 & 3 \\
\hline łódzkie & 5 & 5 & 8 & 5 & 4 & 4 & 6 & 5 & 4 \\
\hline dolnośląskie & 6 & 6 & 7 & 6 & 6 & 6 & 5 & 6 & 2 \\
\hline pomorskie & 7 & 7 & 6 & 7 & 8 & 7 & 9 & 7 & 3 \\
\hline mazowieckie & 8 & 8 & 12 & 10 & 7 & 8 & 7 & 8 & 5 \\
\hline lubelskie & 9 & 9 & 11 & 9 & 10 & 9 & 8 & 9 & 3 \\
\hline świętokrzyskie & 10 & 10 & 14 & 13 & 9 & 10 & 10 & 10 & 5 \\
\hline małopolskie & 11 & 11 & 13 & 11 & 11 & 11 & 13 & 12 & 2 \\
\hline zachodniopomorskie & 12 & 12 & 5 & 8 & 12 & 12 & 11 & 13 & 8 \\
\hline podlaskie & 13 & 13 & 15 & 15 & 13 & 14 & 14 & 14 & 2 \\
\hline warmińsko-mazurskie & 14 & 14 & 10 & 12 & 14 & 13 & 12 & 11 & 4 \\
\hline lubuskie & 15 & 15 & 9 & 14 & 15 & 15 & 15 & 15 & 6 \\
\hline podkarpackie & 16 & 16 & 16 & 16 & 16 & 16 & 16 & 16 & 0 \\
\hline
\end{tabular}

*Rozstęp jest różnicą pomiędzy najwyższą i najniższą pozycją

Źródło: opracowanie własne.

W roku 2014 (tab. 5., kolumna 1.) na najwyższej pozycji w rankingu sporządzonym ze względu na potencjał rolnictwa, znajduje się województwo opolskie, a następnie śląskie, wielkopolskie, kujawsko-pomorskie, łódzkie, dolnośląskie, pomorskie i mazowieckie. Na pozycjach dziewiątej i poniżej natomiast uplasowały się województwa lubelskie, świętokrzyskie, małopolskie, zachodniopomorskie, podlaskie, warmińsko-mazurskie, lubuskie i podkarpackie. 
Tabela 6. Miary podobieństwa 8 rankingów w latach 2006 i 2014

\begin{tabular}{|c|c|c|c|c|c|c|c|c|}
\hline \multirow[t]{2}{*}{ Lata } & \multicolumn{8}{|c|}{$\bar{u}_{p}$ dla rankingu } \\
\hline & R1 & R2 & R6 & R8 & R5 & R4 & R7 & R3 \\
\hline 2006 & 0,950 & 0,947 & 0,947 & 0,946 & 0,931 & 0,926 & 0,915 & 0,898 \\
\hline 2014 & 0,967 & 0,966 & 0,965 & 0,961 & 0,957 & 0,953 & 0,950 & 0,910 \\
\hline
\end{tabular}

Źródło: opracowanie własne.

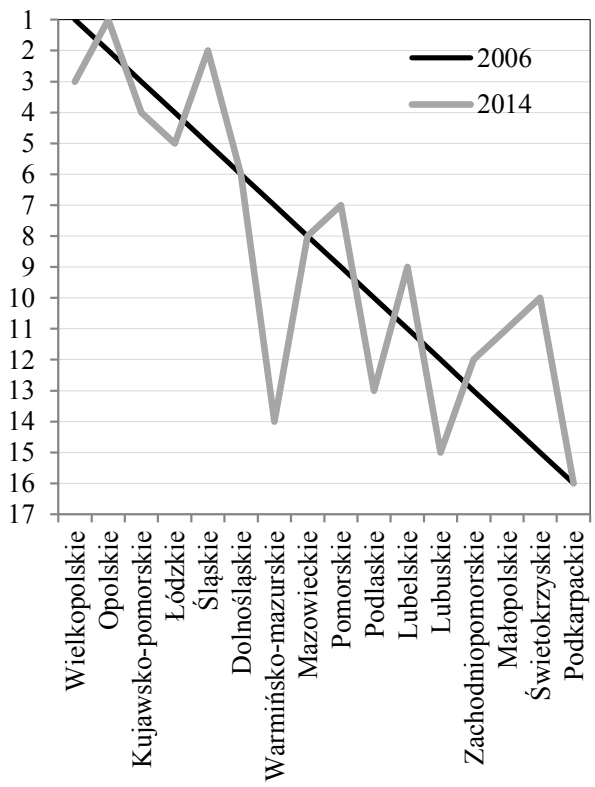

Rysunek 1. Pozycje województw uzyskane metodą R1 w latach 2006 i 2014 Źródło: opracowanie własne

Pozytywne zmiany potencjału (tab. 5 . i rys. 1.) względem innych województw w latach 2006-2014 nastąpiły w województwach świętokrzyskim (zmiana o 5 pozycji w górę), śląskim i małopolskim (o 3 pozycje), pomorskim i lubelskim (o 2 pozycje) oraz opolskim i zachodniopomorskim (o 1 pozycję). Pozycji nie zmieniły województwa dolnośląskie, mazowieckie i podkarpackie. Potencjał rolnictwa najbardziej zmniejszył się w województwie warmińsko-mazurskim (spadek o 7 pozycji), podlaskim i lubuskim (o 3 pozycje), wielkopolskim (o 2 pozycje) oraz kujawsko-pomorskim i łódzkim (o 1 pozycję). Województwa te słabiej niż inne wykorzystały szanse, jakie otworzyły się przed nimi w związku z przystąpieniem Polski do UE $\mathrm{i}$ istotnym wsparciem finansowym, które było tego konsekwencją.

Zmiany pozycji województw w badanym okresie zobrazowano na rysunku 1. Wśród województw o wyższym potencjale w 2006 roku (znajdujących się na pozycjach 1-8) dwa województwa poprawiły pozycję, cztery obniżyły, a dwa nie zmieniły jej.

Wśród województw o niższym potencjale w 2006 roku (znajdujących się na pozycjach 9-16) pięć województw poprawiło pozycję, dwa obniżyło, jedno zaś jej nie zmieniło. Oznacza to, że wśród słabszych województw przeważała tendencja wzrostowa, a wśród silnych spadkowa. Może to świadczyć, o wyrównywaniu w badanym okresie różnic w potencjale rolnictwa pomiędzy województwami.

Województwa zostały podzielone na pięć klas typologicznych, zgodnie z regułami przedstawionymi wcześniej. W 2014 roku poszczególne klasy obejmowały następujące województwa:

- $\quad$ klasa I (bardzo wysoki potencjał rolnictwa) - opolskie, śląskie i wielkopolskie,

- klasa II (wysoki potencjał rolnictwa) - dolnośląskie, kujawsko-pomorskie i łódzkie,

- klasa III (średni potencjał rolnictwa) - lubelskie, mazowieckie i pomorskie,

- klasa IV (niski potencjał rolnictwa) - małopolskie, świętokrzyskie i zachodniopomorskie,

- klasa V (bardzo niski potencjał rolnictwa) - lubuskie, podkarpackie, podlaskie i warmińsko-mazurskie. 
W klasie I znalazły się województwa o wysokich wartościach środków trwałych i produkcji globalnej, wysokim zużyciu nawozów i wysokich nakładach inwestycyjnych (z wyjątkiem województwa wielkopolskiego). W klasie tej przeważały województwa o wysokim udziale UR w powierzchni oraz gruntów zmeliorowanych i małym udziale ugorów. Liczba zatrudnionych na 100 ha była w dwóch województwach zdecydowanie poniżej średniej, ale w jednym zdecydowanie powyżej (śląskie).

W klasie II wartość środków trwałych oraz nakładów inwestycyjnych były na poziomie średnim i poniżej, poziom dochodów powyżej średniej, zużycie nawozów wysokie. Udział UR w powierzchni wysoki (większy niż w klasie I), udział zmeliorowanych UR, podobnie jak w klasie I, wysoki i mały udział ziemi odłogowanej. Liczba zatrudnionych na 100 ha była bardzo niska i średnia (w łódzkim).

Klasa III objęła województwa o średniej wartości środków trwałych i globalnej produkcji rolniczej, średnim zużyciu nawozów, w dwóch województwach nakłady inwestycyjne były niskie, w jednym średnie (w pomorskim). Udział UR w powierzchni był zróżnicowany (poniżej i powyżej średniej), udział zmeliorowanych UR był niski (z wyjątkiem województwa pomorskiego), udział ziemi odłogowanej średni i niski (w lubelskim). Liczba zatrudnionych na 100 ha była bardzo niska w jednym województwie (w pomorskim), w pozostałych zaś średnia.

W klasie IV znalazły się dwa województwa o dosyć wysokim poziomie środków trwałych i jedno o bardzo niskich (zachodniopomorskie), średniej globalnej produkcji rolniczej, niższym od średniego zużyciu nawozów i dosyć wysokich nakładach inwestycyjnych (z wyjątkiem województwa zachodniopomorskiego). Niski był udział UR w powierzchni i udział gruntów zmeliorowanych (z wyjątkiem zachodniopomorskiego, dla którego był większy od średniej), udział ugorów niski w dwóch województwach i wysoki w jednym (zachodniopomorskim). Liczba zatrudnionych na 100 ha była bardzo wysoka w dwóch województwach i bardzo niska w jednym (zachodniopomorskie). Województwo zachodniopomorskie jest w tej grupie nietypowe, choć łącznie ocena jego potencjału jest podobna do pozostałych.

Klasa V objęła cztery województwa o bardzo niskiej wartości środków trwałych (z wyjątkiem podkarpackiego - poziom średni), niskim i bardzo niskim poziomie produkcji globalnej i bardzo niskim zużyciu nawozów. W dwóch województwach nakłady inwestycyjne były relatywnie wysokie (lubuskie i podkarpackie), w dwóch pozostałych bardzo niskie. Udział UR był niski i bardzo niski (z wyjątkiem podlaskiego - wysoki), niski udział gruntów zmeliorowanych (z wyjątkiem warmińsko-mazurskiego, gdzie był bardzo wysoki), wysoki udział odłogów (z wyjątkiem podlaskiego, gdzie był średni). Liczba zatrudnionych na 100 ha była bardzo niska i niska w trzech województwach i bardzo wysoka w jednym (podkarpackie).

Wartości pojedynczych zmiennych diagnostycznych w poszczególnych klasach może cechować dosyć duży rozrzut. W jednej klasie mogą znaleźć się obiekty o relatywnie dużych i relatywnie małych ich wartościach. Dopiero miara łączna (zmienna syntetyczna) pozwala na określenie właściwej pozycji obiektu. Słabość pod względem jednego kryterium (tu cechy) może być bowiem rekompensowana siłą innych. Ze względu na duże rozrzuty wartości oraz małą liczebność obiektów w klasach obliczanie średnich wartości nie wydaje się w tym przypadku odpowiednie. Charakteryzując klasy można jedynie oceniać poziomy poszczególnych cech dla większości zawartych w niej obiektów.

Na rysunku 2. przedstawiono przestrzenne zróżnicowanie potencjału rolniczego województw w latach 2006 i 2014. Największy potencjał miały województwa centralno-zachodnie 

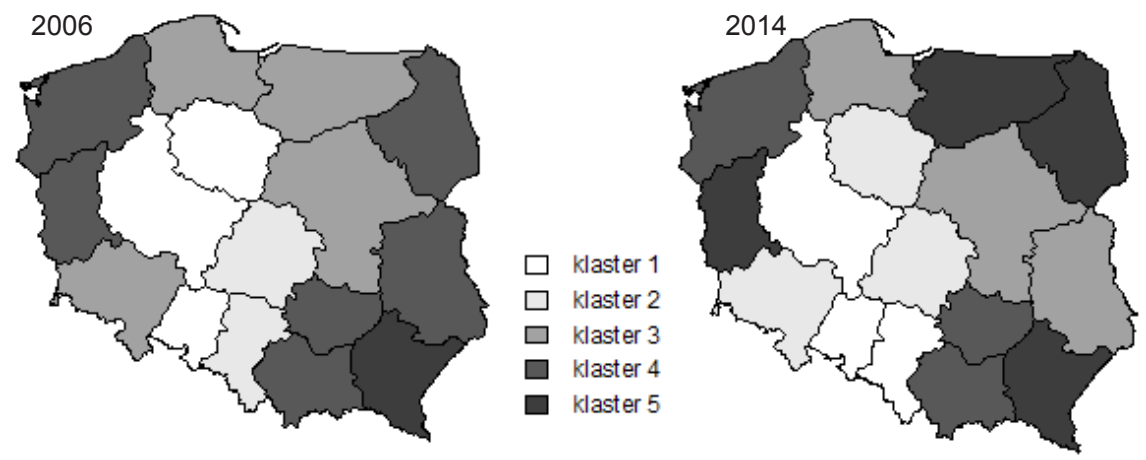

Rysunek 2. Podział na klasy na postawie ZS uzyskanej metodą R1 w latach 2006 i 2014 Źródło: opracowanie własne.

i centralno-południowe, najniższy zaś głównie graniczne. Zmiany klas w badanym okresie (awans o 1 klasę) wystąpiły dla województw dolnośląskiego, lubelskiego i śląskiego. Spadek o 1 klasę dotyczył kujawsko-pomorskiego, lubuskiego i podlaskiego. Relatywnie najbardziej potencjał obniżył się w województwie warmińsko-mazurskim - spadek o dwie klasy.

\section{WNIOSKI}

Z przeprowadzonych badań wyciągnąć można następujące wnioski:

1. Analizy jednowymiarowe potencjału rolniczego pokazały, że nie ma województw, w których wszystkie zmienne diagnostyczne przyjmują wartości najbardziej bądź najmniej pożądane. Nie można więc na jej podstawie dokonać oceny badanego zjawiska złożonego, co wskazuje na potrzebę stosowania analizy wielowymiarowej.

2. Rankingi sporządzone różnymi metodami były dosyć podobne, choć pozycje zajmowane przez poszczególne województwa mogły się znacznie różnić. Wskazuje to na potrzebę stosowania procedur pozwalających wybrać jeden ranking, który uznać można za ostateczny.

3. W 2014 roku na najwyższej pozycji w ostatecznym rankingu sporządzonym ze względu na potencjał rolnictwa znalazło się województwo opolskie, a następnie śląskie, wielkopolskie, kujawsko-pomorskie, łódzkie, dolnośląskie, pomorskie i mazowieckie. Na pozycjach dziewiątej i poniżej niej - województwa lubelskie, świętokrzyskie, małopolskie, zachodniopomorskie, podlaskie, warmińsko-mazurskie, lubuskie i podkarpackie.

4. W latach 2006-2014 pozytywne zmiany potencjału rolniczego względem innych województw wystąpiły w województwach świętokrzyskim, śląskim i małopolskim, pomorskim i lubelskim oraz opolskim i zachodniopomorskim. Pozycji nie zmieniły województwa dolnośląskie, mazowieckie i podkarpackie. Potencjał rolnictwa relatywnie najbardziej zmniejszył się w województwach warmińsko-mazurskim, podlaskim, lubuskim, wielkopolskim oraz kujawsko-pomorskim i łódzkim (o 1 pozycję). Województwa te słabiej niż inne wykorzystały istotne wsparcie finansowe rolnictwa po przystąpieniu do UE. 
5. Wśród województw znajdujących się na pozycjach 1-8 (o wyższym potencjale) w 2006 roku w 2014 dwa poprawiły pozycję, cztery obniżyły, a dwa nie zmieniły. Wśród województw znajdujących się na pozycjach 9-16 (o niższym potencjale) w 2006 roku w 2014 pięć poprawiło pozycję, dwa obniżyło, jedno zaś jej nie zmieniło. A zatem odnotowano wyrównywanie $\mathrm{w}$ badanym okresie różnic w potencjale rolnictwa pomiędzy województwami.

6. W 2014 roku bardzo wysoki potencjał miało rolnictwo w województwach opolskim, śląskim i wielkopolskim, wysoki w dolnośląskim, kujawsko-pomorskim i łódzkim, średni w lubelskim, mazowieckim i pomorskim, niski w małopolskim, świętokrzyskim i zachodniopomorskim, bardzo niski w lubuskim, podkarpackim, podlaskim i warmińsko-mazurskim.

7. Wartości pojedynczych zmiennych diagnostycznych w poszczególnych klasach może cechować dosyć duży rozrzut, bowiem w jednej klasie mogą znaleźć się obiekty o relatywnie dużych i małych ich wartościach. Właściwą pozycję województwa pokazuje miara łączna (zmienna syntetyczna).

\section{LITERATURA}

ARiMR, 2016: http://www.arimr.gov.pl/pomoc-unijna/wdrazane-programy-i-dzialania-dane-liczbowe/zrealizowane-platnosci-obszarowe.html, dostęp: 20.12.2016.

Bartosiewicz Stanisława, 1976: Propozycja metody tworzenia zmiennych syntetycznych, „Zeszyty Naukowe Akademii Ekonomicznej we Wrocławiu", nr 84, s. 5-7.

Binderman Agata, 2005: Klasyfikacja polskich województw wedlug poziomu rozwoju rolnictwa, „Roczniki Nauk Rolniczych. Seria G”, t. 92, z. 1, s. 42-53.

Borys Tadeusz, 1978: Metody normowania cech w statystycznych badaniach porównawczych, „Przegląd Statystyczny”, 25(2), s. 227-239.

Gatnar Eugeniusz, Marek Walesiak (red.), 2004: Metody statystycznej analizy wielowymiarowej w badaniach marketingowych, Wydawnictwo Akademii Ekonomicznej im. Oskara Langego we Wrocławiu, Wrocław.

Grabiński Tadeusz, 1992: Metody taksonometrii, Wydawnictwo Akademii Ekonomicznej w Krakowie, Kraków.

GUS, 2007: Rocznik statystyczny rolnictwa i obszarów wiejskich, Warszawa.

GUS, 2015: Rocznik statystyczny rolnictwa, Warszawa.

Hellwig Zdzisław, 1968: Zastosowanie metody taksonomicznej do typologicznego podziału krajów ze względu na poziom ich rozwoju oraz zasoby i strukturę wykwalifikowanych kadr, „Przegląd Statystyczny", 15(4), s. 307-327.

Kisielińska Joanna, Stanisław Stańko, 2009: Wielowymiarowa analiza danych w ekonomice rolnictwa, „Roczniki Nauk Rolniczych, Seria G”, t. 96, z. 2, s. 63-76.

Kisielińska Joanna, 2016: Ranking państw UE ze względu na potencjalne możliwości zaspokojenia zapotrzebowania na produkty rolnicze z wykorzystaniem metod porzadkowania liniowego, „Zeszyty Naukowe SGGW w Warszawie. Problemy Rolnictwa Światowego”, t. 16(XXXI), z. 3, s. 142-152.

Kukuła Karol, 1986: Propozycja miary zgodności układów porzadkowych, „Zeszyty Naukowe Akademii Ekonomicznej w Krakowie", Kraków, nr 22.

Kukuła Karol, 2000: Metoda unitaryzacji zerowanej, PWN, Warszawa.

Kukuła Karol, 2012: Propozycja procedury wspomagającej wybór metody porzadkowania liniowego, „Metody Ilościowe w Badaniach Ekonomicznych”, 13(1), s. 5-16.

Kukuła Karol, 2014: Budowa rankingu województw ze względu na wyposażenie techniczne rolnictwa w Polsce, „Wiadomości Statystyczne”, nr 7, s. 49-64.

Kukuła Karol, Lidia Luty, 2015a: Propozycja procedury wspomagajacej wybór metody porząkowania liniowego, „Przegląd Statystyczny”, 62(2), s. 219-231. 
Kukuła Karol, Lidia Luty, 2015b: Ranking państw UE ze względu na wybrane wskaźniki charakteryzujace rolnictwo ekologiczne, „Metody Ilościowe w Badaniach Ekonomicznych”, t. XVI, nr 3, s. 225-236.

Lira Jarosław, Wiesław Wagner, Feliks Wysocki, 2002: Mediana w zagadnieniach porządkowania obiektów wielocechowych, [w] Statystyka regionalna w stużbie samorzadu lokalnego i biz$n e s u$, red. Jan Paradysz, Internetowa Oficyna Wydawnicza Centrum Statystyki Regionalnej, Akademia Ekonomiczna w Poznaniu, s. 87-99.

Łuczak Aleksandra, Feliks Wysocki, 2013: Zastosowanie mediany przestrzennej Webera i metody TOPSIS w ujęciu pozycyjnym do konstrukcji syntetycznego miernika poziomu życia, „Prace Naukowe Uniwersytetu Ekonomicznego we Wrocławiu”, Wrocław, nr 278, s. 63-73.

Majchrzak Anna, Feliks Wysocki, 2007: Potencjat produkcyjny rolnictwa w województwie wielkopolskim, „Roczniki Naukowe SERiA”, t. IX, z. 2, s. 217-221.

Nowak Anna, Agnieszka Kamińska, Monika Różańska-Baczuła, 2014: Przestrzenne zróżnicowanie potencjału produkcyjnego rolnictwa w Polsce, „Prace Naukowe Uniwersytetu Ekonomicznego we Wrocławiu", Wrocław, nr 347, s. 363-372.

Nowak Anna, Ewa Wójcik, 2013: Potencjat produkcyjny rolnictwa województw Polski wschodniej. „Roczniki Naukowe SERiA”, t. XV, z. 2, s. 233-238.

Nowak Edward, 1977: Syntetyczne mierniki plonów w krajach europejskich. „Wiadomości Statystyczne", nr 10, s. 19-22.

Orłowska Maria, 2014: Regionalne zróżnicowanie potencjału oraz efektywności czynników produkcji gospodarstw rolniczych w Polsce w świetle FADN. „Roczniki Naukowe SERiA”, t. XVI, z. 1, s. 163-169.

Osowska Luiza, Dorota Janiszewska, 2013: Potencjat produkcyjny i uwarunkowania rozwoju rolnictwa w województwie zachodniopomorskim, „Zeszyty Naukowe SGGW w Warszawie. Problemy Rolnictwa Światowego", t. 13(XXVIII), z. 2, s. 68-78.

Panek Tomasz, 2009: Statystyczne metody wielowymiarowej analizy porównawczej, SGH, Oficyna Wydawnicza, Warszawa.

Pawełek Barbara 2008: Metody normalizacji zmiennych w badaniach porównawczych zlożonych zjawisk ekonomicznych, „Zeszyty Naukowe Uniwersytetu Ekonomicznego w Krakowie. Seria specjalna: Monografie", 187, s. 246.

Poczta Walenty, Natalia Bartkowiak, 2012: Regionalne zróżnicowanie rolnictwa w Polsce, ,Journal of Agribusiness and Rural Development", nr 1(23), s. 95-109.

Poczta Walenty, Małgorzata Kołodziejczak, 2004: Potencjat produkcyjny rolnictwa polskiego $i$ efektywność gospodarowania w aspekcie integracji z Unia Europejska, Wydawnictwo Akademii Rolniczej w Poznaniu, Poznań.

Poczta Walenty, Karolina Pawlak, 2010: Potencjat polskiego rolnictwa pięć lat po akcesji Polski do UE jako przesłanka jego konkurencyjności, „Wieś i Rolnictwo”, nr 1(146), s. 21-47.

Strahl Danuta, 1978: Propozycja konstrukcji miary syntetycznej, „Przegląd Statystyczny”, 25(2), s. $205-215$.

Walesiak Marek, 2011: Uogólniona miara odległości GDMw statystycznej analizie wielowymiarowej z wykorzystaniem programu $R$, Wydawnictwo Uniwersytetu we Wrocławiu. Wrocław.

Walesiak Marek, 2014: Przeglad formut normalizacji wartości zmiennych oraz ich własności w statystycznej analizie wielowymiarowej, „Przegląd Statystyczny”, 61(4), s. 363-372.

Walesiak Marek, 2016: Wybór grup metod normalizacji wartości zmiennych w skalowaniu wielowymiarowym, „Przegląd Statystyczny”, 63(1), s. 7-18.

Wasilewska Ewa, 2009: Statystyka opisowa od podstaw. Podręcznik z zadaniami, Wydawnictwo SGGW, Warszawa.

Woś Augustyn, Franciszek Tomczak (red.), 1983: Ekonomika rolnictwa. Zarys teorii, PWRiL, Warszawa.

Wysocki Feliks, Agnieszka Kozera, 2012: Potencjat produkcyjny rolnictwa i efektywność wykorzystania czynników produkcji, „Wiadomości Statystyczne”, $\mathrm{nr}$ 4, s. 49-64.

Zeliaś Aleksander, 2002: Uwagi na temat wyboru metody normowania zmiennych diagnostycznych, [w] Analiza szeregów czasowych na początku XXI wieku, red. Tadeusz Kufel, Mariola Piłatowska, Uniwersytet M. Kopernika w Toruniu, Toruń. 


\section{Joanna Kisielińska}

\section{VOIVODSHIPS RANKING ACCORDING TO THE POTENTIAL OF AGRICULTURE}

\section{Summary}

The aim of the research presented in the article was to compare the potential of agriculture in voivodships and to evaluate the changes in the potential in the period from 2006 to 2014. The evaluation was based on rankings prepared with the use of selected methods of linear ordering developed according to the effectiveness and potential of agricultural production, not its size. With the use of rankings similarity measure the best rankings were selected for both years. Synthetic variables they were based on were then used to distinguish typological classes. A division into five groups based on mean and standard deviation was proposed.

Adres do korespondencji: dr hab. Joanna Kisielińska, prof. SGGW Katedra Ekonomiki Rolnictwa i Międzynarodowych Stosunków Gospodarczych 02-787 Warszawa, ul. Nowoursynowska 166 tel. (0 22) 5934262 e-mail: joanna_kisielinska@sggw.pl 